\title{
Growth Characteristics of a Species of Lipomyces and its Degradation of Paraquat
}

\author{
BY J. R. ANDERSON AND ELIZABETH A. DREW \\ Imperial Chemical Industries, Plant Protection Limited, Jealott's Hill \\ Research Station, Bracknell, Berkshire, $R G \mathrm{I}_{2} 6 E Y$
}

(Accepted for publication 27 September 197I)

\section{SUMMARY}

A Lipomyces sp. of soil yeast, probably of the 'starkeyi' or 'lipofer' type, degraded paraquat over a wide range of $\mathrm{pH}$ and temperatures, extreme values of which reduced growth but not paraquat degradation. The organism withstood high concentrations of the herbicide.

Growth in nitrogen-depleted broth amended with paraquat showed a lag phase of about $24 \mathrm{~h}$. There was no lag with $\left(\mathrm{NH}_{4}\right)_{2} \mathrm{SO}_{4}$ either alone or with paraquat, but in the latter case paraquat degradation was delayed for $24 \mathrm{~h}$.

A $24 \mathrm{~h}$ exposure to paraquat and a carbon source was necessary for synthesis of the paraquat-catabolizing system.

The organism grew well on soil extract and malt extract and media containing $\left(\mathrm{NH}_{4}\right)_{2} \mathrm{SO}_{4}$ or $\mathrm{NH}_{4} \mathrm{NO}_{3}$ as nitrogen sources; it grew with urea or $\mathrm{NaNO}_{2}$ after a lag of $24 \mathrm{~h}$ or longer, but not on biuret or $\mathrm{NaNO}_{3}$. Atmospheric $\mathrm{N}_{2}$ was fixed in the presence of added molybdate. The presence of alternative nitrogen sources did not prevent or delay paraquat degradation.

A variety of mono-, di- and polysaccharide materials was used as carbon and energy source. Growth was not obtained with powdered cellulose, carboxy-methylcellulose, lactose or paraquat as sole carbon source. The organism was unable to ferment carbohydrates or degrade paraquat anaerobically; it degraded commercial formulations of paraquat, but growth and degradation were affected by increasing concentrations of formulating additives.

\section{INTRODUCTION}

Of several soil organisms originally reported (Baldwin, Bray \& Geoghegan, 1966) to be capable of degrading the herbicide $\mathrm{I}, \mathrm{I}^{\prime}$-dimethyl-4,4'-bipyridylium (paraquat), only a yeast, resembling the type species Lipomyces starkeyi Lodder and Kreger-van Rij (Lodder \& Kreger-van Rij, 1952) has given consistent and reproducible results in culture. This organism, isolated from paraquat-treated soil, has been shown to decompose ${ }^{14} \mathrm{C}$-ring labelled paraquat in a medium containing the herbicide as sole nitrogen source, and to liberate 82 to $84 \%$ of the labelled carbon as ${ }^{14} \mathrm{CO}_{2}$ (Baldwin et al. 1966). This paper describes some characteristics of growth of the organism in the presence and absence of paraquat.

\section{METHODS}

Media. The organism was routinely maintained on $2 \%(\mathrm{w} / \mathrm{v})$ malt extract agar slants. For growth and degradation studies, a basal nitrogen-free ( $\mathrm{N}$-free) broth was used, containing (g/l deionized water): sucrose, $10.0 ; \mathrm{KH}_{2} \mathrm{PO}_{4}, \mathrm{I} \cdot 0 ; \mathrm{KCl}, 0.5 ; \mathrm{MgSO}_{4} \cdot 7 \mathrm{H}_{2} \mathrm{O}, 0.5 ; \mathrm{FeSO}_{4}$. $2 \mathrm{H}_{2} \mathrm{O}, 0.02$. As nitrogen source, paraquat dichloride or $\left(\mathrm{NH}_{4}\right)_{2} \mathrm{SO}_{4}$ was added and the $\mathrm{pH}$ adjusted to $6 \cdot 8$. Kjeldahl analyses of the basal $\mathrm{N}$-free broth showed an average of $700 \mu \mathrm{g}$ 
total $\mathrm{N} / 1$ of broth. In addition, $2 \%(\mathrm{w} / \mathrm{v})$ malt extract broth, buffered to $\mathrm{pH} 6.8$ with Sörensen's phosphate buffer $(0.03 \mathrm{M})$, and soil extract broth in which soil extract (Pramer \& Schmidt, 1964) replaced deionized water in basal N-free broth, were used in some instances. All media were steam-sterilized at $15 \mathrm{lb} / \mathrm{in}^{2}$ for $20 \mathrm{~min}$, under which conditions paraquat is stable.

For identification of the yeast, the methods of Lodder \& Kreger-van Rij (I952) were followed and the mineral salts medium used was ( $\mathrm{g} / \mathrm{l}$ deionized water): $\left(\mathrm{NH}_{4}\right)_{2} \mathrm{SO}_{4}, 5^{\circ} 0$; $\mathrm{KH}_{2} \mathrm{PO}_{4}, \mathrm{I} \cdot 0 ; \mathrm{MgSO}_{4} \cdot 7 \mathrm{H}_{2} \mathrm{O}, 0.5$. The medium was adjusted to $\mathrm{pH} 6.8$ and for carbon assimilation studies, glucose, galactose, sucrose, maltose and lactose were added separately to a final concentration of $2 \%(\mathrm{w} / \mathrm{v})$. Ethanol was used at a concentration of $\mathrm{I} \cdot 5 \% \mathrm{v} / \mathrm{v})$. For fermentation studies, a $5 \%(\mathrm{w} / \mathrm{v})$ yeast extract broth with $2 \%(\mathrm{w} / \mathrm{v})$ of glucose, fructose, galactose, maltose, sucrose, lactose, melibiose or raffinose was used with Durham tubes. For studies on ability to grow on nitrate nitrogen, $\mathrm{KNO}_{3}(0.8 \mathrm{~g} / \mathrm{l})$ replaced $\left(\mathrm{NH}_{4}\right)_{2} \mathrm{SO}_{4}$ in the above mineral salts medium with sucrose as carbon source. Ability to form spores was tested using potato dextrose and Gorodkowa's agar (Lodder \& Kreger-van Rij, I952).

Culture. Unless otherwise stated, all experiments were conducted at $22^{\circ}$ with gyrotary shaking. Inoculum was made by suspending loopfuls of cells from a $48 \mathrm{~h}$ old slant in Io $\mathrm{ml}$ sterile water. Sometimes the inoculum was washed three times in sterile normal saline to minimize nitrogenous carry-over from malt agar slants.

Growth evaluation. Growth was evaluated by haemocytometer counts (Thoma ruling) of samples taken immediately after inoculation and at appropriate intervals thereafter.

Analytical. A modified ion-exchange resin column technique (Calderbank \& Yuen, I965) was used for paraquat residues in broth. Paraquat was extracted from samples that had been refluxed for I $\mathrm{h}$ with $\mathrm{N}_{-} \mathrm{H}_{2} \mathrm{SO}_{4}$ (final concentration) and eluted from the columns with saturated aqueous $\mathrm{NH}_{4} \mathrm{Cl}$. Statistical analysis of paraquat recovery by this method showed a standard error of $6 \%$. An alternative method was based on intensity of colour produced after addition of $\mathrm{I} \cdot 0 \mathrm{ml}$ of a mixture of $\mathrm{I} \cdot 0 \%(\mathrm{w} / \mathrm{v})$ sodium dithionite in $\mathrm{N}-\mathrm{NaOH}$ to $9.0 \mathrm{ml}$ of centrifuged culture supernatant. These reagents were used within $\mathrm{I} \mathrm{h}$ of preparation and the blue colour developing because of the presence of paraquat was read at $490 \mathrm{~nm}$ immediately.

Induction studies. The basal $\mathrm{N}$-free broth contained sufficient contaminant nitrogen to initiate and support growth for about $72 \mathrm{~h}$. It was therefore necessary to inoculate $\mathrm{N}$-free broth with washed cells and incubate for $72 \mathrm{~h}$ to deplete the medium of nitrogen. The medium was then aseptically transferred to, and centrifuged in, sealed sterile centrifuge tubes at $40,000 \mathrm{~g}$ for $30 \mathrm{~min}$ to remove the yeast and cell debris. The supernatant was decanted in a sterile-air cabinet, pipetted into sterile flasks and re-inoculated from a thricewashed dilution of the centrifuged yeast. Millipore filtration was unsuitable due to the presence of ammoniacal nitrogen in the membrane and/or prefilter. The nitrogen sources (see Fig. 8) were autoclaved before incorporating them aseptically in flasks. Further evidence for induction was sought by making dense suspensions of yeast in $\mathrm{N}$-free broth amended with paraquat $\left(\mathrm{I} \cdot 0 \times 1 \mathrm{O}^{-4} \mathrm{M}\right)$ with and without a carbon and energy source. Flasks of paraquatamended $\mathrm{N}$-free broth were inoculated at $24 \mathrm{~h}$ intervals from these sources. Inoculum size was adjusted for increases or decreases in the yeast suspension counts.

Growth on alternative nitrogen sources. The basal $\mathrm{N}$-free medium was amended with various nitrogenous compounds (see Results). It was also made with soil extract replacing deionized water and was then found to contain $1 \cdot 7 \times 10^{-3} \mathrm{M}$ total $\mathrm{N}$.

To examine the possibility of nitrogen fixation by the organism, $\mathrm{NaMoO}_{4}(500 \mu \mathrm{g} / \mathrm{l})$ was added to the basal $\mathrm{N}$-free medium. 
Triplicate flasks were inoculated and then inactivated with $\mathrm{I}^{2} \mathrm{~N}-\mathrm{H}_{2} \mathrm{SO}_{4}$ ( $\mathrm{I} \mathrm{ml}$ ) and put at $-20^{\circ}$. Comparable flasks were incubated for Io days and then inactivated in the same manner. Micro-Kjeldahl analyses were conducted on both sets of flasks.

To determine the ability of the organism to use paraquat in the presence of other nitrogen compounds, these were used together with $\mathrm{I}^{\circ} \mathrm{O} \times \mathrm{IO}^{-4} \mathrm{M}$-paraquat. The ability to degrade paraquat in the presence of increasing concentrations of $\mathrm{NH}_{4}{ }^{+}$ions was examined using basal $\mathrm{N}$-free medium amended with $\mathrm{I} \cdot 0 \times 10^{-4} \mathrm{M}$-paraquat and four levels of $\mathrm{NH}_{4} \mathrm{NO}_{3}$ (Table 5). Samples were removed from duplicate flasks at $24 \mathrm{~h}$ intervals for seven days and analysed colorimetrically for residual paraquat.

In all nitrogen utilization studies, inoculum from $72 \mathrm{~h}$ nitrogen-deficient mineral salts slants was used after washing in sterile normal saline and resuspending in sterile deionized water.

Growth on alternative carbon sources. Basal N-free broth was formulated with sucrose, glucose, maltose, glycerol, starch, apple pectin, finely ground cellulose powder and carboxymethylcellulose each at I \% (w/v). Except for apple pectin, which was steam sterilized at $100^{\circ}$ on three consecutive days, all carbohydrates were Millipore filtered $(0.22 \mu \mathrm{m}$ pore size). Plant leaf residue, as ${ }^{14} \mathrm{C}$-labelled Canna leaf which had been exhaustively refluxed in $80 \%$ ethanol to remove soluble carbohydrates (available in this form from The Radiochemical Centre, Amersham, Buckinghamshire), was used at I $\mathrm{mg}$ in $20 \mathrm{ml}$ basal $\mathrm{N}$-free broth with and without supplementary sucrose. In all the above media $\mathrm{I} \cdot 0 \times 10^{-4} \mathrm{M}$-paraquat served as nitrogen source together with $0.7 \mathrm{I} \times \mathrm{IO}^{-4} \mathrm{M}^{-}\left(\mathrm{NH}_{4}\right)_{2} \mathrm{SO}_{4}$. The ${ }^{14} \mathrm{C}$-plant leaf residue flasks were evaluated visually for growth, and the ${ }^{14} \mathrm{CO}_{2}$ evolved was measured by scintillation counting of the ethanolamine sink.

Effect of anaerobic incubation. Inoculated basal $\mathrm{N}$-free broth with $\mathrm{I} \cdot 0 \times 1 \mathrm{IO}^{-4} \mathrm{M}$-paraquat was incubated with and without $2 \cdot 0 \times 10^{-3} \mathrm{M}-\mathrm{NaNO}_{3}$ or $\mathrm{Na}_{2} \mathrm{SO}_{4}$ as possible electron acceptors in anaerobic jars chemically depleted of oxygen. Incubation was for 14 days at $24^{\circ}$ without shaking.

Effect of commercially formulated paraquat. Basal $\mathrm{N}$-free broth was amended with paraquat ion and also with the equivalent concentrations of paraquat added as 'Gramoxone W', the commercially available formulation of paraquat (Imperial Chemical Industries, Plant Protection Limited, Fernhurst, Haselmere, Surrey). In all cases $\left(\mathrm{NH}_{4}\right) \mathrm{SO}_{4}\left(4^{\circ} 0 \times \mathrm{IO}^{-4} \mathrm{M}\right)$ was present as an alternative nitrogen source.

Equivalent concentrations of 'Gramoxone W' formulating agents alone were also used, with $\left(\mathrm{NH}_{4}\right)_{2} \mathrm{SO}_{4}\left(4^{\circ} \cdot 0 \times 10^{-4} \mathrm{M}\right)$ as the sole nitrogen source.

\section{RESULTS}

\section{Effects of $p H$, temperature and paraquat concentration}

An increased yeast count, from $\mathrm{I} \cdot 2 \times 10^{3}$ to $2 \cdot 3 \times 10^{3}$ yeasts per $\mathrm{ml}$ occurred when acetate or acetic acid was used as sole carbon source. This was regarded as negligible for the purposes of the $\mathrm{pH}$ experiment, the results of which (Fig. I-3) indicate a wide tolerance of $\mathrm{pH}$ for growth in malt extract and $\mathrm{N}$-free mineral salts media and a narrower tolerance to $\mathrm{pH}$ changes in soil-extract broth. The latter medium showed an optimum for growth on the acid side of neutrality, whereas in the other two media the optima tended towards neutral to alkaline values. In the malt and mineral salts medium paraquat was degraded at most $\mathrm{pH}$ values but at a decreased rate at extreme values in both cases. In soil extract, rate of degradation was reduced at extremely acid $\mathrm{pH}$ values and was not detected at values of $\mathrm{pH} 8 \cdot 4$ or above (Table I). 


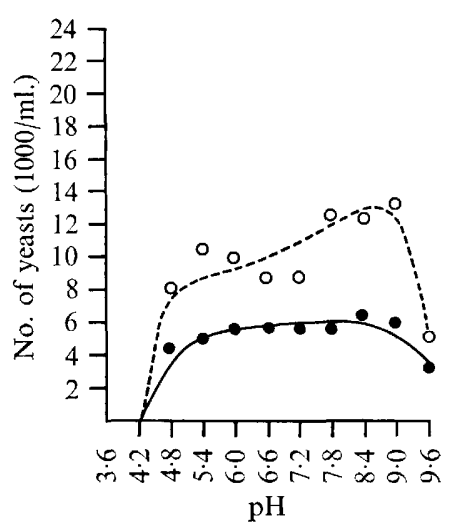

Fig. I

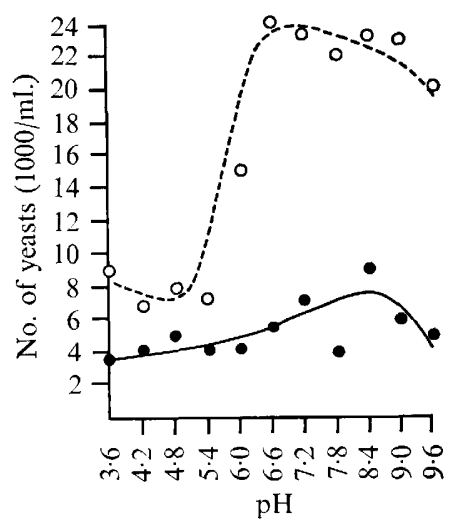

Fig. 2

Fig. I. Effect of pH on growth of Lipomyces sp. in $2 \%$ malt extract broth with $\mathrm{x} \cdot 0 \times 1 \mathrm{IO}^{-4} \mathrm{M}$-paraquat. Growth after three days $(\longrightarrow)$ and seven days $(O--O)$. For buffers, see Table I.

Fig. 2. Effect of $\mathrm{pH}$ on growth of Lipomyces sp. in basal $\mathrm{N}$-free mineral salts broth with $\mathrm{I} \cdot 0 \times \mathrm{IO}^{-4} \mathrm{M}-$ paraquat. Growth after three days $(\longrightarrow)$ and seven days $\left(\mathrm{O}_{---}\right)$. For buffers, see Table $\mathrm{I}$.

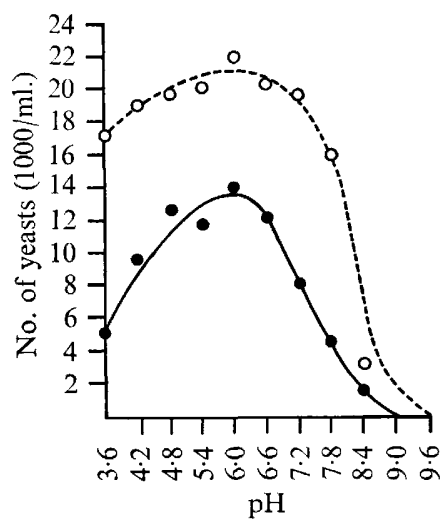

Fig. 3. Effect of $\mathrm{pH}$ on growth of Lipomyces sp. in soil extract broth with $\mathrm{I} \cdot 0 \times 10^{-4} \mathrm{M}$-paraquat. Growth after three days $(-)$ ) and seven days $(\mathrm{O}--\mathrm{O})$. For buffers see Table $\mathbf{r}$.

In temperature experiments, yeast numbers were lower due to the static incubation of flasks. Increased yeast counts over the inoculum level were detected at all temperatures, the greatest increase being at $26^{\circ}$ in the mineral salts medium (Fig. 4). Some restriction on degradation at temperatures below $20^{\circ}$ and above $35^{\circ}$ was found after three days' incubation but degradation was complete at all temperatures, except $39^{\circ}$, after seven days (Table 2).

Growth curves of the yeast in malt broth with increasing paraquat concentrations are shown in Fig. 5. At concentrations of $5.4 \times 10^{-5} \mathrm{M}$ and $5.4 \times 10^{-4} \mathrm{M}$, growth was virtually identical. At $2 \cdot 7 \times 10^{-3} \mathrm{M}$, growth rate into the exponential phase was slower and at $5.4 \times 10^{-3} \mathrm{M}$, a $24 \mathrm{~h}$ lag was apparent which increased to 72 and $96 \mathrm{~h}$ at $2.7 \times 10^{-2} \mathrm{M}$ and $5 \cdot 4 \times 10^{-2} \mathrm{M}$, respectively.

Growth with $2 \cdot 7 \times 10^{-1} \mathrm{M}$-paraquat was delayed for about $156 \mathrm{~h}$. When washed cells from the exponential phase of cultures containing $2.7 \times 10^{-2} \mathrm{M}$ were used as inoculum, a decrease 


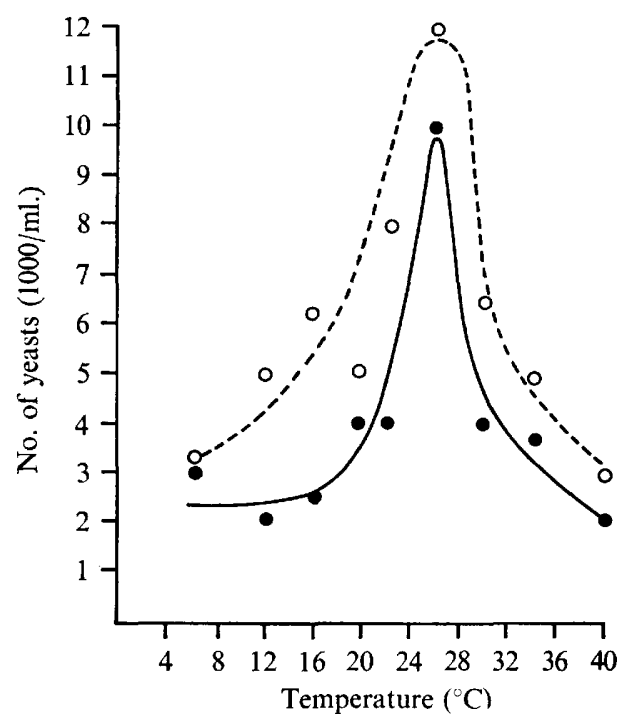

Fig. 4. Effect of temperature on growth of Lipomyces sp. in basal $\mathrm{N}$-free mineral salts broth with $\mathrm{I} \cdot \mathrm{O} \times \mathrm{IO}^{-4} \mathrm{M}$-paraquat. Growth after three days $(-\rightarrow)$ and seven days $(\mathrm{O}---\mathrm{O})$.

in lag was observed from 72 to $24 \mathrm{~h}$ in mineral salts broth containing $2.7 \times 10^{-2} \mathrm{M}$ and from 96 to $48 \mathrm{~h}$ in the presence of $5.4 \times 10^{-2} \mathrm{M}$-paraquat (Fig. 6). Corresponding flasks of mineral salts broth inoculated from paraquat-free agar slants showed a $72 \mathrm{~h}$ and $96 \mathrm{~h}$ lag at $2 \cdot 7 \times 10^{-2} \mathrm{M}$ and $5.4 \times 10^{-2} \mathrm{M}$-paraquat, respectively.

Table I. Effects of $p H$ on ability of Lipomyces sp. to degrade $10^{-4} \mathrm{M}$ paraquat in three media at $22^{\circ}$

\begin{tabular}{|c|c|c|c|}
\hline \multirow[b]{2}{*}{$\mathrm{pH} \dagger$} & \multicolumn{3}{|c|}{$\%$ Paraquat degraded* after 3 days in } \\
\hline & $\begin{array}{c}\text { Malt } \\
\text { extract }\end{array}$ & $\begin{array}{l}\text { Mineral } \\
\text { salts }\end{array}$ & $\begin{array}{c}\text { Soil } \\
\text { extract }\end{array}$ \\
\hline $3 \cdot 6$ & $0 \cdot 0$ & 0.0 & $70 \cdot 0$ \\
\hline $4 \cdot 2$ & $12 \cdot 3$ & $77 \cdot 1$ & 80.0 \\
\hline $4 \cdot 8$ & $70 \cdot 5$ & $84 \cdot 6$ & $100 \cdot 0$ \\
\hline $5 \cdot 4$ & $100 \cdot 0$ & $87 \cdot 9$ & $100 \cdot 0$ \\
\hline $6 \cdot 0$ & 93.4 & $58 \cdot 3$ & $100 \cdot 0$ \\
\hline $6 \cdot 6$ & 95.4 & $5 \mathrm{I} \cdot 8$ & $100 \cdot 0$ \\
\hline $7 \cdot 2$ & $94 \cdot 7$ & $35 \cdot 5$ & $100 \cdot 0$ \\
\hline $7 \cdot 8$ & $90 \cdot 5$ & $46 \cdot 9$ & $50 \cdot 0$ \\
\hline $8 \cdot 4$ & $94 \cdot I$ & $99 \cdot \mathrm{I}$ & 0.0 \\
\hline $9 \cdot 0$ & $92 \cdot 6$ & $68 \cdot 0$ & 0.0 \\
\hline $9 \cdot 6$ & $49 \cdot 3$ & $50 \cdot 8$ & $0 \cdot 0$ \\
\hline
\end{tabular}

* After seven days' incubation paraquat degradation was $100 \%$ in mineral salts broth at all pH values. In malt extract broth degradation was $100 \%$ at all $\mathrm{pH}$ values except $\mathrm{pH} 3.6$ and 4.2 where the values were $5 \mathrm{I} \cdot 8 \%$ and $50.1 \%$ respectively. In soil extract broth, degradation was $100 \%$ at all pH values except pH $8 \cdot 4$, 9.0 and 9.6 where no degradation was recorded.

$\dagger$ For the pH ranges 3.6 to 5.4 and 6.0 to $8 \cdot 4$, sodium acetate-acetic acid (0.03 M) and Sörensen's phosphate buffer $(0.03 \mathrm{M})$, respectively, were used. For $\mathrm{pH} 9.0$ and 9.6 sodium carbonate-bicarbonate buffer $(0.03 \mathrm{M})$ was used.

$\ddagger$ Soil extract (Pramer \& Schmidt, 1964) replaced deionized water in the basal N-free medium. 


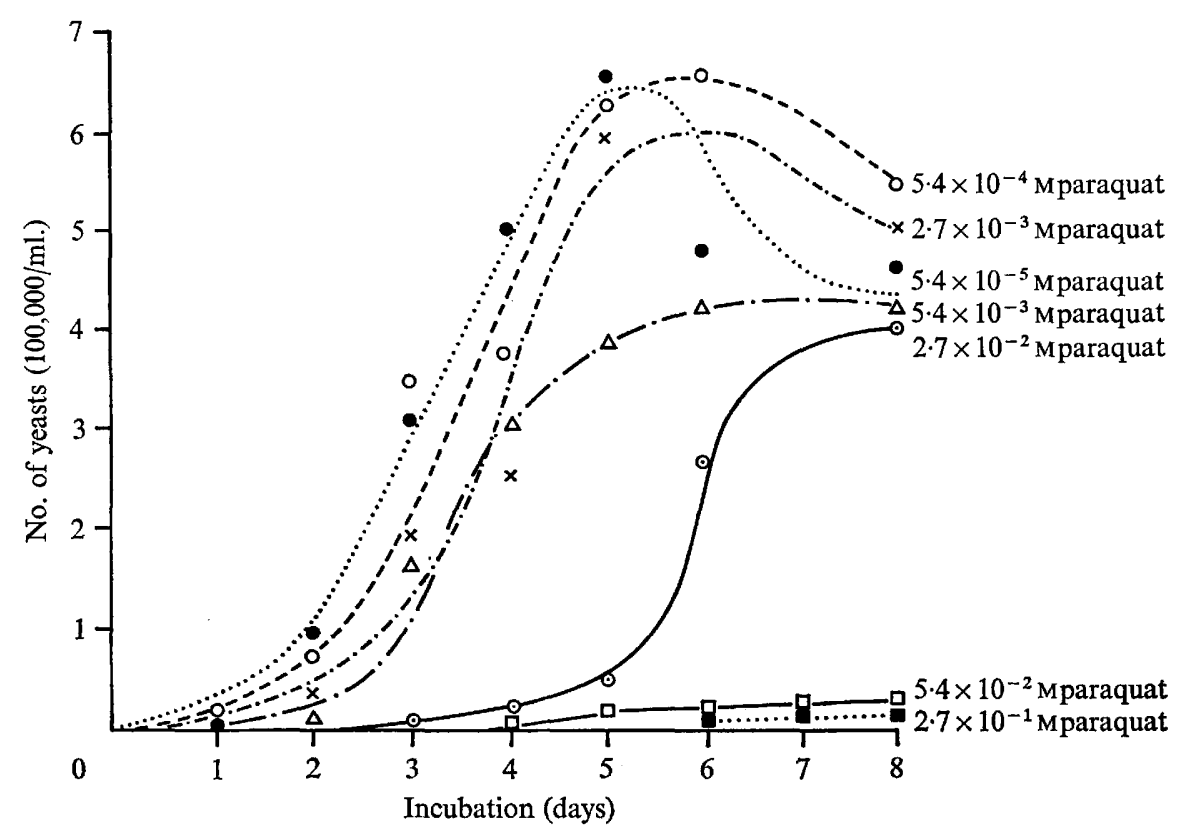

Fig. 5. Growth of Lipomyces sp. in $2 \%$ malt extract broth with increasing concentrations of paraquat. Yeast numbers corrected for initial inoculum.

\section{Inducibility of Lipomyces sp. to paraquat catabolism}

As indicated in Fig. 7, small amounts of contaminant nitrogen in the basal N-free mineral salts broth were capable of supporting limited growth of the organism. When this nitrogen was depleted, the re-inoculated medium did not support growth of the organism. When $\mathrm{N}$-depleted medium was augmented with paraquat, the organism underwent a 12 to $24 \mathrm{~h}$ lag phase, whereas with $\left(\mathrm{NH}_{4}\right)_{2} \mathrm{SO}_{4}$, or paraquat and $\left(\mathrm{NH}_{4}\right)_{2} \mathrm{SO}_{4}$, no appreciable lag was apparent (Fig. 8). With the combined nitrogen source, growth was similar to that on $\left(\mathrm{NH}_{4}\right)_{2}$ $\mathrm{SO}_{4}$ alone, but paraquat degradation was detected only at the $48 \mathrm{~h}$ sampling period. Values for degradation were $0,20.4$ and $58.3 \%$ for the 24,48 and $72 \mathrm{~h}$ periods respectively, compared with $5.0,34 \cdot \mathrm{I}$ and $63.9 \%$ for the same periods on paraquat as sole nitrogen source. With $\left(\mathrm{NH}_{4}\right)_{2} \mathrm{SO}_{4}$ as sole nitrogen source, growth and $\mathrm{NH}_{4}{ }^{+}$ion utilization commenced within the first $24 \mathrm{~h}$.

Table 2. Effects of temperature on ability of Lipomyces sp. to degrade $10^{-4} \mathrm{M}-$ paraquat in mineral salts medium, $\mathrm{pH}_{7 \cdot 2}$ in static culture

$\begin{array}{cccr}\text { Paraquat } & \begin{array}{c}\text { Paraquat } \\ \text { degraded* } \\ \text { after 3 days }\end{array} & \text { Temp. }\left(^{\circ}\right) & \begin{array}{r}\text { Pagraded } \\ \text { after 3 days }\end{array} \\ (\%)\end{array}$

\footnotetext{
* Paraquat degradation was $100 \%$ at all temperatures after seven days, except at $39^{\circ}$ where no degradation was recorded.
} 


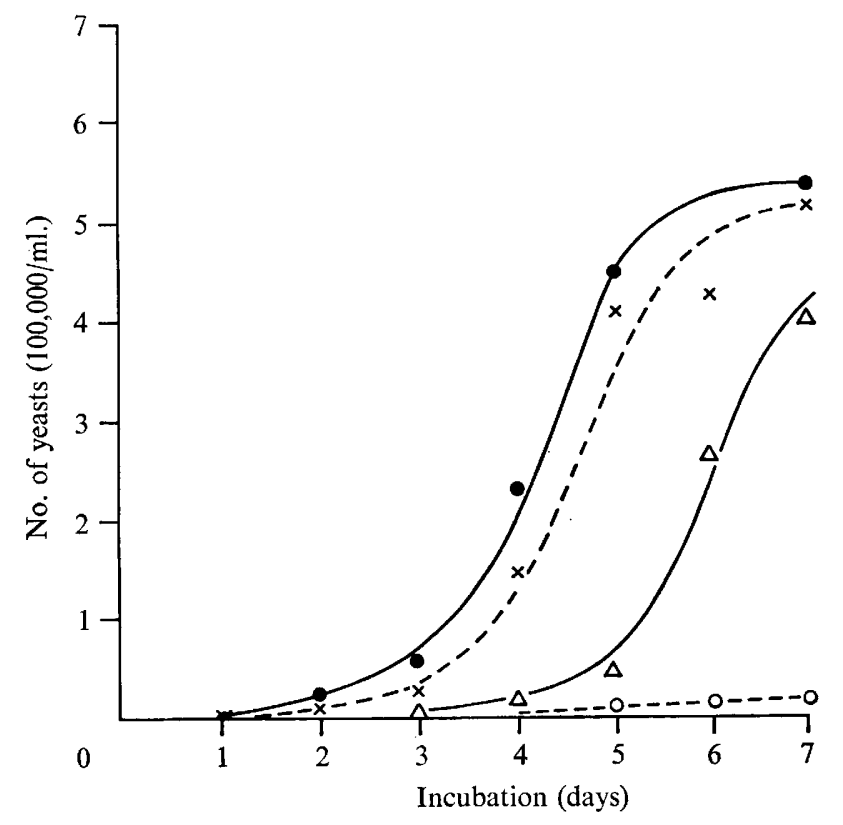

Fig. 6. Growth of paraquat-exposed Lipomyces sp. in basal N-free mineral salts broth with $2 \cdot 7 \times$ $10^{-2} \mathrm{M}(-)$ and $5.4 \times 10^{-2} \mathrm{M}(\times--\infty \times)$ paraquat. Growth of unexposed cells in $2 \cdot 7 \times 10^{-2} \mathrm{M}$ $(\triangle-\triangle)$ and $5.4 \times 10^{-2} \mathrm{M}(\mathrm{O}---O)$ paraquat. Yeast numbers corrected for initial inoculum.

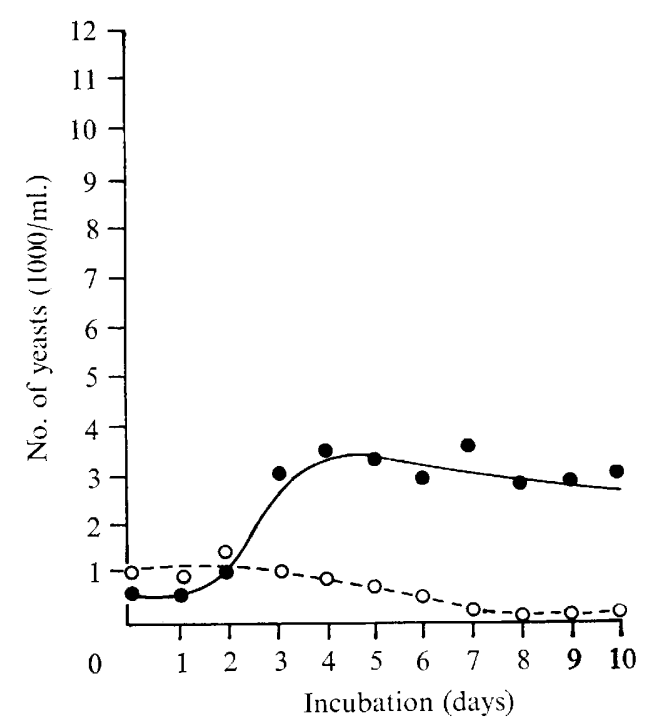

Fig. 7 Yeast numbers of Lipomyces sp. in basal N-free mineral salts broth without added nitrogen $(-)$ and in corresponding nitrogen-depleted broth without added nitrogen $(\bigcirc---\bigcirc)$. 


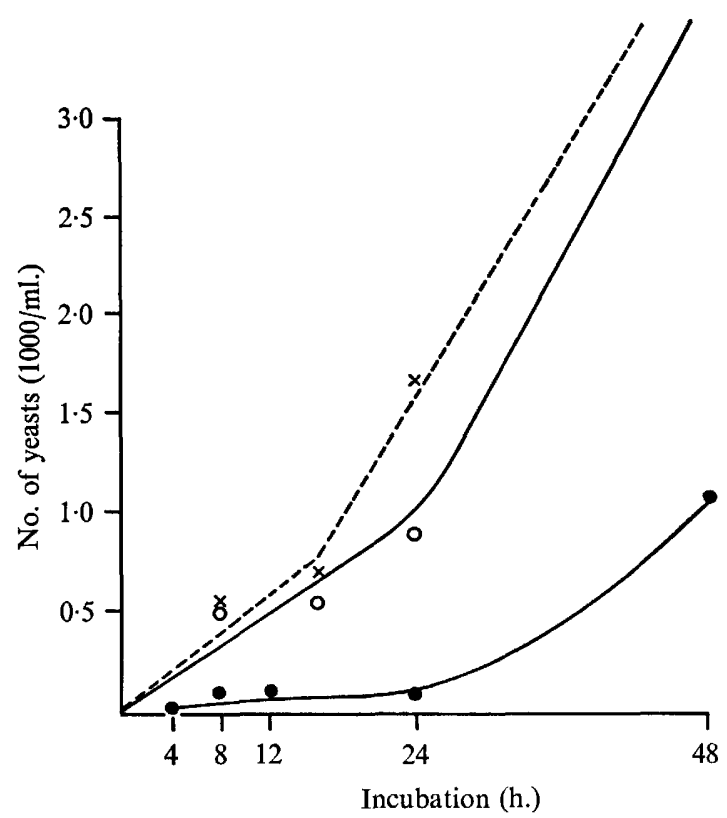

Fig. 8. Yeast numbers (corrected for initial inoculum) of Lipomyces sp. in nitrogen-depleted basal $\mathrm{N}$-free mineral salts broth with paraquat $(-\longrightarrow)$, ammonium sulphate $(\mathrm{O}-\mathrm{O})$ and both paraquat and ammonium sulphate $(x---x)$ as nitrogen sources. Concentrations of paraquat and ammonium sulphate were $1.0 \times 10^{-4} \mathrm{M}$ and $0.71 \times 10^{-4} \mathrm{M}$ respectively.

The sequential inoculations, with heavy supensions of cells of basal $\mathrm{N}$-free broth amended with paraquat, with and without a carbon source, showed that an exposure of up to $24 \mathrm{~h}$ to the complete form (Fig. 9) of the broth was necessary for synthesis of appropriate enzymes. Exposure of cells in incomplete broth gave results which are not understood. There was a lag after the first two sequential inoculations ( 24 and $48 \mathrm{~h}$ ), but longer exposures in this broth lacking an energy source resulted in no growth after transfer to the fresh (complete) medium.

Table 3. Effects of decreasing sucrose concentration on paraquat and ammonium ion utilization by Lipomyces sp. after seven days' incubation in mineral salts medium

\begin{tabular}{|c|c|}
\hline $\begin{array}{c}\text { Sucrose } \\
\text { concentration } \\
(\%, w / v)\end{array}$ & $\begin{array}{l}\text { Nitrogen } \\
\text { source* }\end{array}$ \\
\hline$I \cdot O$ & $\begin{array}{l}\text { Paraquat } \\
\text { Paraquat }+\mathrm{NH}_{4}{ }^{+}\end{array}$ \\
\hline $0 \cdot I$ & $\begin{array}{l}\text { Paraquat } \\
\text { Paraquat }+\mathrm{NH}_{4}{ }^{+}\end{array}$ \\
\hline 0.01 & $\begin{array}{l}\text { Paraquat } \\
\text { Paraquat }+\mathrm{NH}_{4}{ }^{+}\end{array}$ \\
\hline 0.001 & $\begin{array}{l}\text { Paraquat } \\
\text { Paraquat }+\mathrm{NH}_{4}{ }^{+}\end{array}$ \\
\hline Nil & $\begin{array}{l}\text { Paraquat } \\
\text { Paraquat }+\mathrm{NH}_{4}+\end{array}$ \\
\hline
\end{tabular}

\begin{tabular}{|c|c|}
\hline \multicolumn{2}{|c|}{ Utilization (\%) } \\
\hline Paraquat & $\mathrm{NH}_{4}{ }^{+}$ \\
\hline 100 & - \\
\hline 100 & 100 \\
\hline 100 & - \\
\hline 99 & 100 \\
\hline 90 & 一 \\
\hline 32 & 100 \\
\hline 10 & - \\
\hline 9 & 65 \\
\hline 0 & - \\
\hline 0 & 0 \\
\hline
\end{tabular}

* Concentrations: $2 \cdot 0 \times 10^{-4} \mathrm{M}$-paraquat, $\mathrm{I} \cdot 4 \times \mathrm{IO}^{-4} \mathrm{M}-\left(\mathrm{NH}_{4}\right)_{2} \mathrm{SO}_{4}$. 


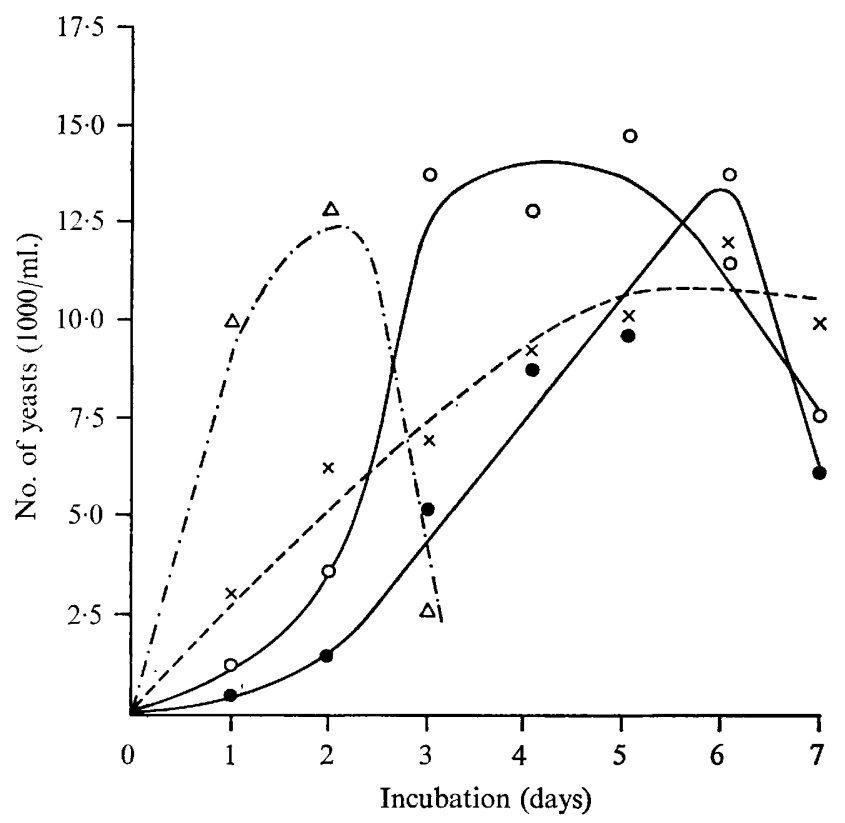

Fig. 9. Growth of Lipomyces sp. in basal $\mathrm{N}$-free mineral salts broth with $\mathrm{I} \cdot 0 \times 10^{-4} \mathrm{M}$-paraquat after exposure to paraquat plus a carbon and energy source for o h $(-0), 24 \mathrm{~h}(\mathrm{O}-\mathrm{O}), 72 \mathrm{~h}$ $(x---x)$, and $\mathrm{I} 20 \mathrm{~h}(\triangle---\triangle)$. Yeast numbers corrected for initial inoculum.

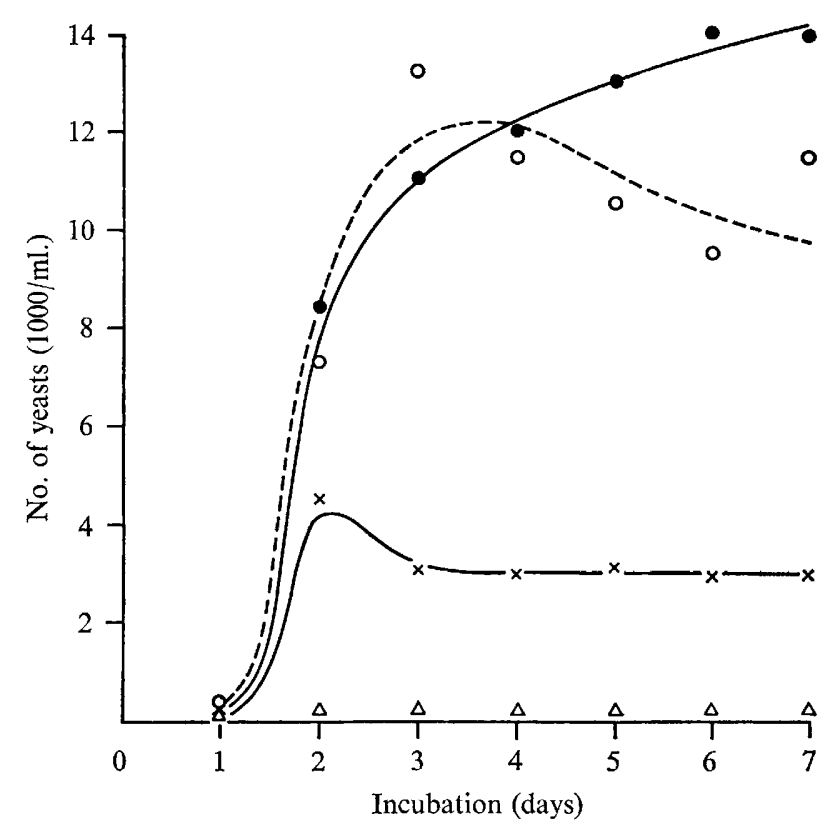

Fig. 10. Growth of Lipomyces sp. in basal $\mathrm{N}$-free broth with $2 \cdot 0 \times 10^{-4} \mathrm{M}$-paraquat and $\mathrm{I} \cdot 0 \%$ sucrose (-O), $0.1 \%$ sucrose $(0---0), 0.01 \%$ sucrose $(x-x)$ and $0.001 \%$ sucrose $(\triangle \longrightarrow \triangle)$. Yeast numbers corrected for initial inoculum. 


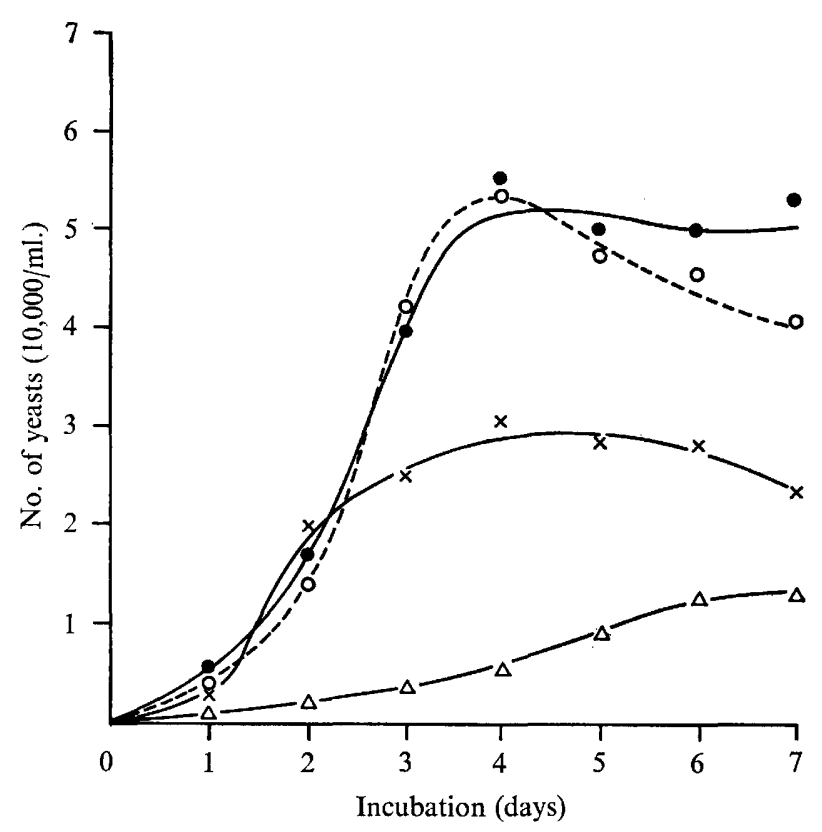

Fig. II .Growth of Lipomyces sp. in basal N-free mineral salts broth with $2.0 \times 10^{-4} \mathrm{M}$ paraquat and $\mathrm{I} \cdot 4 \times 10^{-4} \mathrm{M}$-ammonium sulphate and $\mathrm{I} \cdot 0 \%$ sucrose $(-0), 0 . \mathrm{I} \%$ sucrose $(\mathrm{O}---0), 0.0 \mathrm{I} \%$ sucrose $(x \longrightarrow x)$, or $0.001 \%$ sucrose $(\triangle \longrightarrow \Delta)$. Yeast numbers corrected for initial inoculum.

\section{Influence of energy-limited media on growth and paraquat degradation}

At sucrose concentrations of $\mathrm{I} \cdot 0$ and $0.1 \%$ (w/v), growth (Fig. I0) and paraquat degradation (Table 3) were of the same order. At sucrose concentrations of 0.01 and $0.001 \%(\mathrm{w} / \mathrm{v})$, growth and degradation were reduced. With $\left(\mathrm{NH}_{4}\right)_{2} \mathrm{SO}_{4}$ and paraquat, growth (Fig. II) was not as severely restricted at the $0.0 \mathrm{I} \%$ level.

No growth, paraquat degradation or $\mathrm{NH}_{4}{ }^{+}$utilization (Table 3 ) occurred in flasks without sucrose, and use of a tenfold greater inoculum in some of these flasks resulted in no increase in yeast numbers or paraquat degradation.

\section{Influence of $\mathrm{Mg}^{2+}$-limitation on growth and paraquat degradation}

When the concentration of $\mathrm{Mg}^{2+}$ was decreased from that in the basal medium, a slight reduction of growth was noted, but when $\mathrm{Mg}^{2+}$ was omitted from the medium very little multiplication of the yeast occurred. Paraquat degradation was unaffected by halving of $\mathrm{Mg}^{2+}$ concentration but was only $13 \%$ in the absence of added $\mathrm{Mg}^{2+}$ ions after seven days' incubation.

\section{Growth on alternative nitrogen sources}

In assessing the ability of the yeast to utilize other forms of nitrogen, the effect of contaminant nitrogen had to be taken into account. By applying a growth-curve correction factor derived from the limited growth on basal $\mathrm{N}$-free mineral-salts broth, a series of growth curves for different nitrogenous substrates was obtained. No delay in the onset of growth was noticeable with $\left(\mathrm{NH}_{4}\right)_{2} \mathrm{SO}_{4}$ or soil extract, but with urea, $\mathrm{NaNO}_{2}$ and paraquat individually, there was a lag of $24 \mathrm{~h}$ or more. There was no growth with $\mathrm{NaNO}_{3}$ or biuret.

In the presence of paraquat and each of the above nitrogenous compounds there was no 
delay in growth with $\left(\mathrm{NH}_{4}\right)_{2} \mathrm{SO}_{4}$ or soil extract but there was a $24 \mathrm{~h}$ delay with urea plus paraquat, biuret plus paraquat, $\mathrm{NaNO}_{2}$ plus paraquat and $\mathrm{NaNO}_{3}$ plus paraquat. Growth in either biuret or $\mathrm{NaNO}_{3}$, each with paraquat, was virtually identical to that with paraquat alone. Growth in higher concentrations $\left(\mathrm{I} \cdot 6 \times \mathrm{IO}^{-3} \mathrm{M}, 8.0 \times 10^{-3} \mathrm{M}\right.$, and $\left.\mathrm{I} \cdot 6 \times \mathrm{IO}^{-2} \mathrm{M}\right)$ of $\mathrm{NaNO}_{2}$ was characterized by a lag of about 24 to $48 \mathrm{~h}$ followed by an increase in yeast numbers and changes in their morphology. Hypha-like protuberances with terminal to subterminal nucleus-like inclusions were observed, and in a few instances the protuberances appeared to fuse or conjugate. No ascospores were observed. The ability to use urea was confirmed by growth on mineral-salts agar with urea $(\mathrm{I} \%$, w/v) and phenol red $(0.002 \%$, w/v). After seven days' incubation a red zone developed around the colonies.

Attempts to establish whether increase in yeast numbers on basal $\mathrm{N}$-free medium alone was due to nitrogen fixation were inconclusive. Kjeldahl analyses after Io days of incubation showed a slight increase in total nitrogen but this was statistically non-significant $(P>0.05)$. Cultures supplemented with $\mathrm{NaMoO}_{4}$, however, showed increases of between 70 and I IO $\mu \mathrm{g}$ $\mathrm{N}$ per $20 \mathrm{ml}$ culture medium and these were significant $(P=0.05)$ (Table 4$)$.

Rate of paraquat degradation was virtually unaffected by increasing concentrations of $\mathrm{NH}_{4} \mathrm{NO}_{3}$. After $48 \mathrm{~h}$ incubation the two highest concentrations of $\mathrm{NH}_{4} \mathrm{NO}_{3}$ reduced the rate of paraquat degradation by $40 \%$, but after $96 \mathrm{~h}$ incubation degradation was complete in all systems (Table 5). Growth in the presence of paraquat and all concentrations of $\mathrm{NH}_{4} \mathrm{NO}_{3}$ was both rapid and profuse.

\section{Growth on alternative carbon sources}

The yeast grew with sucrose, glucose, maltose, glycerol, starch, apple pectin and soil extract as sole energy and carbon sources in basal $\mathrm{N}$-free broth with $\mathrm{I} \cdot 0 \times 1 \mathrm{I}^{-4} \mathrm{M}$-paraquat or $0 \cdot 7 \mathrm{I} \times 10^{-4} \mathrm{M}-\left(\mathrm{NH}_{4}\right)_{2} \mathrm{SO}_{4}$ or both. In each case paraquat was degraded. With glycerol, the organism underwent a I4-day lag with paraquat as sole $\mathrm{N}$ source and a 5-day lag with both forms of $\mathrm{N}$. The yeast did not multiply with finely powdered cellulose or with carboxymethyl cellulose in the presence of either form of $\mathrm{N}$.

Table 4. Changes in total nitrogen in 'nitrogen-free' mineral salts broth cultures of Lipomyces sp. with and without added molybdenum

\begin{tabular}{|c|c|c|c|c|}
\hline Medium & Treatment* & Total N/flask $(\mu \mathrm{g})$ & Mean & $\begin{array}{l}\text { Treatment } \\
\text { difference }{ }^{\dagger}\end{array}$ \\
\hline $\begin{array}{l}\text { Mineral salts } \\
\text { Mineral salts }\end{array}$ & $\begin{array}{l}\text { Acid killed } \\
\text { Incubated }\end{array}$ & $\begin{array}{l}70 \cdot 0,70 \cdot 0,70 \cdot 0,87 \cdot 5 \\
70 \cdot 0,70 \cdot 0,105 \cdot 0,\end{array}$ & $\left.\begin{array}{l}74 \cdot 375 \\
81 \cdot 60\end{array}\right\}$ & $7 \cdot 225$ \\
\hline Mineral salts + Mo & Acid killed & $70 \cdot 0,70 \cdot 0,87.5,87.5$ & $78 \cdot 75\}$ & \\
\hline Mineral salts + Mo & Incubated & $98.0,105.0,105.0,105.0$ & $103 \cdot 25\}$ & $24 \cdot 5$ \\
\hline
\end{tabular}

* All flasks were inoculated. Acid killed denotes the inactivation of the organism with I ml $18 \mathrm{~N}-\mathrm{H}_{2} \mathrm{SO}_{4}$ followed by freezing at $-20^{\circ}$. Incubated denotes flasks which were incubated at $22^{\circ}$ for 10 days.

$\dagger$ Value obtained by subtracting 'acid killed' values from 'incubated' values.

Table 5. Effects of increasing ammonium nitrate concentrations on rate of paraquat degradation by Lipomyces sp. in basal $N$-free mineral salts broth with $\mathrm{IO}^{-4} \mathrm{M}-$-paraquat

Degradation of paraquat (\%) after

\begin{tabular}{|c|c|c|c|c|c|}
\hline Concn of $\mathrm{NH}_{4} \mathrm{NO}_{3}$ & $24 \mathrm{~h}$ & $48 \mathrm{~h}$ & $72 \mathrm{~h}$ & $96 \mathrm{~h}$ & $\mathrm{I} 20 \mathrm{~h}$ \\
\hline - & 0 & $56 \cdot 0$ & $83^{\circ} 0$ & $100 \cdot 0$ & - \\
\hline $\mathrm{I} \cdot 25 \times 10^{-4} \mathrm{M}$ & 0 & $56 \cdot 0$ & $80 \cdot 0$ & $99 \cdot 7$ & $100 \cdot 0$ \\
\hline $\mathrm{I} \cdot 25 \times 10^{-3} \mathrm{M}$ & 0 & $54^{\circ} \mathrm{O}$ & $83 \cdot 0$ & $100 \cdot 0$ & - \\
\hline $6.25 \times 10^{-3} \mathrm{M}$ & o & $32 \cdot 0$ & 55.0 & $100 \cdot 0$ & - \\
\hline $\mathrm{I} \cdot 25 \times 10^{-2} \mathrm{M}$ & 0 & $31 \cdot 0$ & $53 \cdot 0$ & $99 \cdot 7$ & $100 \cdot 0$ \\
\hline
\end{tabular}


On ${ }^{14} \mathrm{C}$-Canna leaf residue, growth was as good as on sucrose. Evolution of ${ }^{14} \mathrm{CO}_{2}$ with time is shown in Table 6. Paraquat degradation was only $50 \%$ after nine days' incubation whereas in the presence of labelled leaf residue and sucrose it was $100 \%$ after nine days. Less ${ }^{14} \mathrm{CO}_{2}$ was evolved in the presence of sucrose than with leaf residue alone.

\section{Effect of anaerobic incubation}

The yeast did not multiply nor was paraquat degraded when the yeast was incubated anaerobically in complete mineral-salts medium containing paraquat, whether alone or supplemented with $\mathrm{NaNO}_{3}$ or $\mathrm{Na}_{2} \mathrm{SO}_{4}$.

\section{Effect of commercially formulated paraquat}

Growth and paraquat degradation with Gramoxone ' $W$ ' at a concentration equivalent to $\mathrm{IO}^{-4} \mathrm{M}$-paraquat was virtually identical to that on pure paraquat ion (Table 7 ). At the equivalent of $10^{-3} \mathrm{M}$-paraquat ion, 'Gramoxone $\mathrm{W}$ ' depressed growth and degradation while at ${ }_{10}^{-2} \mathrm{M}$-paraquat equivalent, no growth or degradation was obtained. On pure paraquat and $\left(\mathrm{NH}_{4}\right)_{2} \mathrm{SO}_{4}$ the yeast grew at all three concentrations but paraquat degradation was not recorded at $10^{-2} \mathrm{M}$ in this experiment after four days' incubation. With $\left(\mathrm{NH}_{4}\right)_{2} \mathrm{SO}_{4}$ as sole $\mathrm{N}$ source and 'Gramoxone W' formulating additives only, growth was obtained only at the lowest concentration of additives (Table 7 ).

Table 6. Utilization of ${ }^{14} \mathrm{C}$-labelled plant leaf residue in the presence of paraquat by Lipomyces sp.

\begin{tabular}{|c|c|c|c|c|c|c|}
\hline \multirow[b]{2}{*}{ Energy source $(\mu \mathrm{g} / \mathrm{ml})$} & & $s$ of plar & idue $(\%)$ & $\mathrm{CO}_{2} \mathrm{aft}$ & & \multirow{2}{*}{$\begin{array}{l}\text { Paraquat } \\
\text { degraded* } \\
\text { after } \\
9 \text { days } \\
(\%)\end{array}$} \\
\hline & 2 days & 3 days & 7 days & 8 days & 9 days & \\
\hline${ }^{14} \mathrm{C}$-leaf residue $(50)$ & 0.60 & $I \cdot 73$ & 3.00 & 3.23 & $3 \cdot 6 \mathrm{I}$ & 50 \\
\hline $\begin{array}{l}{ }^{14} \mathrm{C} \text {-leaf residue }(50) \\
\& \text { sucrose }(100)\end{array}$ & $0 \cdot 13$ & 0.40 & 0.82 & 0.85 & $\mathrm{I} \cdot 02$ & 100 \\
\hline Controlt & 0.04 & 0.08 & O.I I & 0.12 & 0.13 & Nil \\
\hline
\end{tabular}

* Paraquat $\left(\mathrm{I} \times 1 \mathrm{IO}^{-4} \mathrm{M}\right)$ and ammonium sulphate $\left(0 \cdot 7 \mathrm{I} \times 10^{-4} \mathrm{M}\right)$ served as combined $\mathrm{N}$ source in basal $\mathrm{N}$-free mineral salts broth.

$\dagger$ Uninoculated broth containing $50 \mu \mathrm{g} / \mathrm{ml}^{14} \mathrm{C}$-plant residue (non-sterile).

Table 7. Influence of formulating additives of 'Gramoxone $W$ ' on growth of Lipomyces sp. and its ability to degrade paraquat in mineral salts broth containing $4.0 \times 1 \mathrm{I}^{-4} \mathrm{M}-\left(\mathrm{NH}_{4}\right)_{2} \mathrm{SO}_{4}$

\begin{tabular}{|c|c|c|c|}
\hline $\begin{array}{l}\text { Concn of } \\
\text { paraquat } \\
(\mathrm{mM})\end{array}$ & $\begin{array}{l}\text { Concn of } \\
\text { formulating } \\
\text { additives* } \\
(\mu 1 / \mathrm{ml})\end{array}$ & $\begin{array}{c}\text { Increase }(+) \text { or } \\
\text { decrease }(-) \text { in } \\
\text { no. yeasts } / \mathrm{ml} \\
\text { after } 4 \text { days } \\
(\%)\end{array}$ & $\begin{array}{l}\text { Paraquat } \\
\text { degraded } \\
\text { after } \\
4 \text { days } \\
(\%)\end{array}$ \\
\hline 0.1 & 0 & +124.0 & 100 \\
\hline 0.1 & 50 & $+\mathrm{I} I 4.5$ & 100 \\
\hline$I \cdot O$ & 0 & $+159^{\circ} 0$ & 100 \\
\hline $\mathbf{I} \cdot 0$ & 500 & +40 & IO \\
\hline $10 \cdot 0$ & 0 & $+125 \cdot 7$ & Nil \\
\hline $10 \cdot 0$ & 5,000 & -4.5 & Nil \\
\hline 0 & 0 & +104.0 & - \\
\hline 0 & 10 & $+104 \cdot 6$ & - \\
\hline 0 & 100 & $-I \cdot 2$ & - \\
\hline 0 & 1,000 & $-\mathrm{I} \cdot 8$ & - \\
\hline
\end{tabular}

* Concentrations in $\mu \mathrm{l} / \mathrm{ml}$ are based on $20 \%(\mathrm{w} / \mathrm{v})$ paraquat concentration and $80 \%$ formulating additives in 'Gramoxone W'. 


\section{Description of the organism}

Carbon assimilation was positive with glucose, galactose, sucrose and maltose each at $2 \%$ $(w / v)$. Results with lactose were inconsistent and, at best, growth was poor after three weeks' incubation. Growth was poor on ethanol $(\mathrm{I} \cdot 5 \%, \mathrm{v} / \mathrm{v})$ after two to three weeks' incubation. No fermentative ability was recorded with any carbon source. Ascospores were produced on potato dextrose agar but not on Gorodkowa's agar. Growth was very weak with $\mathrm{NaNO}_{3}$.

Colonies on agar were raised, glistening and mucous. On agar slants there was a tendency for creamy, watery growth which accumulated at the base of the slant. The yeasts were ovoid with a well-defined capsule in carbohydrate media. They measured, on average, 6 to $8 \mu \mathrm{m}$ by 8 to $10 \mu \mathrm{m}$ exclusive of the capsule. A well-defined refractile body was present as well as one or two vacuoles of varying size. The cell contents did not appear granular.

Asci developed from active buds. From two to eight ascospores per ascus were observed. The spores were amber to brown and contained a refractile body.

The organism was capable of $\mathrm{N}$ fixation in the presence of $\mathrm{NaMoO}_{4}$.

\section{DISCUSSION}

The organism was capable of growth and paraquat degradation over a wide range of $\mathrm{pH}$ values. In $\mathrm{N}$-free mineral salts media, growth might be expected to reflect the extent of paraquat degradation but this was not so, especially after the first three days of incubation. In chemically ill-defined media, where growth need not reflect extent of paraquat degradation, the ability to degrade was less affected at very acid $\mathrm{pH}$ values than was extent of cell proliferation in malt extract. In soil extract there was an apparent optimum $\mathrm{pH}$ range for cell proliferation between $\mathrm{pH} 5.0$ and 6.5 , whereas high paraquat degradation was obtained between $\mathrm{pH} 3.6$ and $7 \cdot 8$. It is possible, therefore, that in all three media $\mathrm{pH}$ may affect the efficiency of paraquat-nitrogen utilization rather than the extent of degradation. Similarly, the efficiency of utilization of energy from the carbon source, which manifests itself in terms of yeast numbers rather than of paraquat degradation may also be affected. The difference between $\mathrm{pH}$ optima in the various media used is not clearly understood.

In evaluating temperature effects in $\mathrm{N}$-free mineral salts medium plus paraquat, degradation was again not reflected by yeast numbers. Whereas a temperature of $26^{\circ}$ was optimal for growth after three days' incubation, complete degradation occurred at $34^{\circ}$, at this temperature yeast numbers were one-third of those at $26^{\circ}$ after either three or seven days. Efficiency of carbon and nitrogen utilization is a likely explanation of these effects. Induction to, and degradation of, paraquat may well occur under conditions which are unfavourable for maximum yeast proliferation.

Concentrations of paraquat up to $2.7 \times \mathrm{IO}^{-3} \mathrm{M}$ were tolerated by the organism, but at higher concentrations there was an increasing lag phase in a medium otherwise capable of supporting growth without paraquat additions. At very high paraquat concentrations $(2 \cdot 7 \times$ $\mathrm{IO}^{-1} \mathrm{M}$ ) osmotic and enzyme inhibition effects may be operating. At concentrations between $5.4 \times \mathrm{IO}^{-3} \mathrm{M}$ and $\mathrm{IO}^{-2} \mathrm{M}$ the delay may be due to transient inhibitions of enzymes, for example succinic or malic dehydrogenase, such as Wallnofer (1968) found with Escherichia coli and bipyridinium compounds.

Evaluation of the constitutive or inducible nature of the paraquat-catabolizing system was complicated by the presence of contaminant nitrogen. The possibility of a nitrogen fixing system in this organism required investigation and the use of nitrogen-depleted broth, while minimizing the contribution of contaminant nitrogen, did not ensure the absence of 
such a mechanism. Fortunately pregrowth of the organism in the medium probably depleted essential trace elements which may have promoted nitrogen-fixation, and the subsequent demonstration that $\mathrm{NaMoO}_{4}$ stimulated fixation permitted the use of nitrogendepleted mineral salts for induction studies.

The presence of a lag phase with nitrogen-depleted broth amended with paraquat, the absence of any appreciable lag with $\left(\mathrm{NH}_{4}\right)_{2} \mathrm{SO}_{4}$, and the fact that paraquat degradation was delayed when both forms of nitrogen were present suggests that the paraquat-degrading enzyme system is induced. In addition, the transfer of washed cells from malt extract containing paraquat to mineral-salts broth with the same, or greater, concentration of paraquat and the resulting shortening of the lag phase is indicative of the presence of induced cells. The transfer of yeast from paraquat media with and without another carbon source to fresh, complete, paraquat medium and the resulting decreased lag, after $24 \mathrm{~h}$ exposure, is also evidence of an induced mechanism.

The evolution of ${ }^{14} \mathrm{CO}_{2}$ from ring-labelled paraquat (Baldwin et al. 1966) indicates that the carbon skeleton of paraquat can be metabolized but the experiments concerned here with energy-limited media provide evidence that induction to and cleavage of the molecule is dependent on a readily available energy source. In the absence of energy, no degradation is obtained as was demonstrated by the use of heavy inocula in paraquat media devoid of any other carbon or energy source. Decreasing availability of sucrose revealed a dependence on energy for paraquat utilization, especially in media containing both paraquat and $\left(\mathrm{NH}_{4}\right)_{2} \mathrm{SO}_{4}$ where the presence of the latter form of nitrogen would promote a greater proliferation of the yeast. This would lead relatively quickly to a situation wherein availability of sucrose, already Ioo-fold less than normal, was at a premium. In the presence of the usual sucrose concentrations, degradation was again impaired when $\mathrm{Mg}^{2+}$ ions were limiting. By inference, utilization of sucrose was limited by the absence of sufficient $\mathrm{Mg}^{2+}$ and therefore insufficient energy was available for growth and paraquat degradation.

Under $\mathrm{pH}$ and temperature conditions which were unfavourable for proliferation of the yeast, paraquat degradation was still obtained after seven days' incubation, but neither did the yeast proliferate nor was paraquat degraded under conditions of $\mathrm{Mg}^{2+}$ or sucrose limitation. These findings suggest that the ring-opening of paraquat is an energy-dependent reaction linked to the oxidation of a suitable energy source and that once it has occurred, the nitrogen and carbon of the paraquat molecule can be utilized provided there is a continued supply of readily oxidizable material.

The organism was capable of obtaining carbon and energy from a variety of substrates. Growth on ${ }^{14} \mathrm{C}$-labelled Canna leaf residue was probably at the expense of residual ethanol and water - insoluble complex plant substances, probably starch although the organism also uses pectin.

The organism used a variety of nitrogenous compounds and, unlike the yeasts studied by Starkey (1946), could fix atmospheric nitrogen in the presence of added molybdate. Ammoniacal and soil-extract nitrogen were the most readily utilized forms of nitrogen. Soil extract supported considerable growth even though nitrate, which the organism could not use, was probably the major form of nitrogen present. The organism grew on what might otherwise be regarded as minimal nitrogen media. Thus the small amounts of ammoniacal and organically bound nitrogen in soil extract were sufficient for growth requirements.

With nitrate or biuret as sole nitrogen source, the growth obtained was barely above that ascribed to contaminant nitrogen in mineral salts broth. Growth on nitrite was greater. Several other yeasts are capable of using nitrite (Abadie, 1968) but not nitrate, probably indicating an incomplete assimilatory nitrate reductase system. The morphological changes encountered 
with nitrite are not clearly understood. Protuberances were produced which were similar to, but longer than, the sac-like shapes occurring during ascopore formation. Since there is no correlation between form of utilizable nitrogen and sporulation frequency (Fowell, 1969) the effect cannot be unequivocally associated with nitrite alone, especially since conjugation of such protuberances in a Lipomyces sp. has been observed previously (Kreger-van Rij, 1969) albeit not on nitrite.

Urea utilization is common in many yeasts (Abadie, 1968). The ability of this isolate to use urea may indicate a urea:aminohydrolase, a urea:dehydrogenase (Omura, Osajima \& Tsukamoto, 1966), or an ATP-dependent enzymic cleavage (Roon \& Levenberg, I968) of urea. The presence of a red zone on urea-phenol red agar is more commonly associated with urea:aminohydrolase. In keeping with the findings of Starkey (1946) that the organism grew on agar media to which no nitrogen was added, colonies appeared on urea agar seven days before the formation of a red zone. This probably indicated a delayed urease synthesis. On urea amended mineral-salts broth, a 24 to $48 \mathrm{~h}$ lag was noted which was long considering that the organism responded well to ammoniacal nitrogen.

The addition of $10^{-4} \mathrm{M}$-paraquat to media containing $\left(\mathrm{NH}_{4}\right)_{2} \mathrm{SO}_{4}, \mathrm{NH}_{4} \mathrm{NO}_{3}, \mathrm{NaNO}_{2}$, urea, soil extract or malt extract neither enhanced nor suppressed growth. Similarly, the presence of utilizable or non-utilizable forms of nitrogen did not affect ability to degrade paraquat. Reports that paraquat degradation is considerably delayed or inhibited by the presence of other utilizable and non-utilizable forms of nitrogen (R. C. Burns, unpublished dissertation; J. Pullen, personal communication) could not be wholly substantiated. A slight delay in rate of paraquat utilization was encountered with some $\mathrm{NH}_{4} \mathrm{NO}_{3}$ concentrations which may be due to the increasing ratio of paraquat: ammonium ions available for assimilation during growth.

The organism degraded paraquat in the presence of additives used in the commercial formulation, ' Graxomone W', but as additive concentration increased, growth and paraquat degradation were impaired. Growth on ammoniacal nitrogen also could be restricted by the addition of formulation additives. These compounds have been implicated in inhibition of growth and respiration of some fungi (Wilkinson \& Lucas, 1969).

The inability of the organism to grow anaerobically is an established feature of Lipomyces species. (Lodder \& Kreger-van Rij, 1952). Under anaerobic conditions paraquat ions are reduced to the radicle which shows as a blue colour in solution. Even with prolonged incubation no detectable degradation occurred.

The identity of the organism cannot be placed beyond the level of the genus Lipomyces with any degree of certainty. It is probably of the 'lipofer' or 'starkeyi' type, but further tests are required to establish this. Even within these species, minor variations occur, and in work yet to be reported, the authors have found paraquat-degrading Lipomyces-type yeasts in many soils in numbers ranging from a few hundred to tens of thousands per gram.

The authors are indebted to Mrs J. Hollies, Mrs K. Prince and Mrs F. Slinger for their invaluable asistance.

\section{REFERENCES}

ABADIE, F. (1968). Assimilation des nitrites et de composses azotes organiques par quelques levures et organismes levuriformes. Annales de l'Institut Pasteur, Paris Ir5, 197-21 I.

Baldwin, B. C., Bray, M. F., \& Geoghegan, M. J. (1966). The microbial decomposition of paraquat. Biochemical Journal ror, I 5 P.

CALDERbank, A. \& Yuen, S. H. (1965). An ion exchange method for determining paraquat residues in food crops. Analyst, London 90, 99-107. 
FowELL, R. R. (1969). Sporulation and hybridization of yeasts. In The Yeasts, vol. I, pp. 303-383. Edited by A. H. Rose \& J. S. Harrison. Academic Press: London.

Kreger-VAN RiJ, N. J.W. (1969). Taxonomy and systematics of yeasts. In The Yeasts., vol. I, pp. 5-78. Edited by A. H. Rose \& J. S. Harrison. London: Academic Press.

LodDer, J. \& Kreger-van RuJ, N.J. W. (1952). The Yeasts - a Taxonomic Study. Amsterdam: North Holland Publishing Co.

Omura, H., Osajma, Y. \& Tsukamoto, T. (1966). Some properties of urea dehydrogenase in tissues of higher plants. Enzymologia: Acta Biocatalytica 31, I29-154.

Pramer, D. \& Schmidt, E. L. (I964). Experimental Soil Microbiology. Minneapolis: Burgess Publishing Co.

ROON, R. J. \& LEVENBERG, B. (1968). An ATP-dependent, avidin sensitive enzymic cleavage of urea in yeast and green algae. The Journal of Biological Chemistry 243, 5213-5215.

STARKey, R. L. (1946). Lipid production by a soil yeast. Journal of Bacteriology 5I, 33-50.

WALLNOFER, P., (1968). Untersuchungen über die antimikrobielle Wirkung von Diequat und Paraquat. Zeitschrift für Pflanzenkrankheiten und Pflanzenschutz 75, 218-224.

Wilkinson, V. \& LUCAS, R. L. (I969). Effects of constituents of 'Gramoxone W' on rates of respiration of soil fungi. Weed Research 9, 288-295. 